\title{
藤田保健衛生大学医学部 認知症・高齢診療科
}

武地一

(日老医誌 $2018 ； 55 ： 420-422$ )

\section{概 要}

本部門は 2016 年 4 月に立ち上がったとても若い部門 です。藤田保健衛生大学は開学が 1968 年, 医学部創立 が 1972 年で, 今年開学 50 周年を迎えます。今年の 10 月には, 50 周年を契機に大学の名前も藤田医科大学と 変更されます。本大学病院は 1,435 床と特定機能病院の 中で最も大きな病床数を有し, 最近, 雑誌などにダヴィ ンチを使ったロボット手術が最も多い病院の一つとして 紹介されることもあります。愛知県の中では名古屋市に 隣接する東尾張地域に位置し, 大学の正門前は名古屋市, 敷地は豊明市という形で, まさに名古屋市の周辺に位置 します。

立地上，名古屋市で最も人口の多い名古屋市緑区と豊 明市を第 1 の医療圈とし 3 分の 1 ぐらいの患者さんはこ の範囲から来院されます。残り 3 分の 2 は名古屋市の他 の区や東尾張, 西三河を中心に広い地域から来られます. 近隣の名所としては織田信長と今川義元が戦った桶狭間 の古戦場があります。

このような地域の中で，高齢者医療や認知症を中心に 診療・研究・教育を行う拠点を大学に作ることを目的に 当科が設立されました，日本老年医学会の専門医として は救急内科の岩田充永教授，連携地域医療学寄付講座の 浅井幹一教授が扮られ，内分泌・代謝内科には骨粗髢症 等を専門にされている鈴木敦詞教授もおられます.また， 老年医学と強く結びっくリハビリテーション科には才藤 栄一教授も扔られるなか，それら諸先生方とも協力させ ていただきつつ，診療科の運営を行っています。

\section{臨床と研究}

当科は設立時, 教授 1 名でスタートし, 病床は持たず, 外来のみの診療で開始しました。認知症看護認定看護師 が 3 名抢り，また，リハビリテーション科との連携の中, リハビリテーション部作業療法士や医療科学部作業療法 科の教官の支援を得て，もの忘れ外来を中心とする外来 運営を開始しました。2016 年 4 月から認知症ケア加算 のスタートとともに本学にも認知症ケアチームを設置 し, 認知症・せん妄・フレイル・サルコペニア・嚥下・ 地域連携などが大きなテーマとなるこのチームの運営を 通じて，老年医学的なアプローチを行っています，本大 学病院では認知症看護認定看護師の加藤滋代さんを中心 に，全国的にも先駆けて院内デイケアを運営してきた害 績があり，認知症ケアチームの活動とリンクして活発に 活動を行っています.チームのソーシャルワーカーの他, 作業療法士，薬剤師も加わり，多職種チームで精力的に 取り組んでいます。ただし，認知症ケアチームが直面す る課題として，基本的には急性期病院であることから在 院日数が短く介入する時間が十分ではないこと，身体合 併症の急性期治療を行う中で認知症ケアとの両立が簡単 では無いこと，病床数が多くマンパワーが足りないこと など，多くの課題を抱えています。逆に，これらは臨床 的にも研究面でもチャレンジを行っていく対象でもあ り，工夫を積み重ねています。

認知症ケアチームで院内に対応する一方，外来の患者 数は近隣からの紹介を中心に順調に伸び，2017 年度か らは精神科の松永慎史講師が当科の外来を担当してくれ るようになり，2018 年 4 月には，松永講師が診療科と しても当科に移ってくれたことで，医局としても漸く教

藤田保健衛生大学医学部認知症 - 高齢診療科

連絡責任者：武地 - 藤田保健衛生大学医学部認知症・高齢診療科〔于470-1192 愛知県豊明市沓掛町田楽ヶ窪 1-98〕

e-mail: takechi@fujita-hu.ac.jp

doi: 10.3143 /geriatrics.55.420 


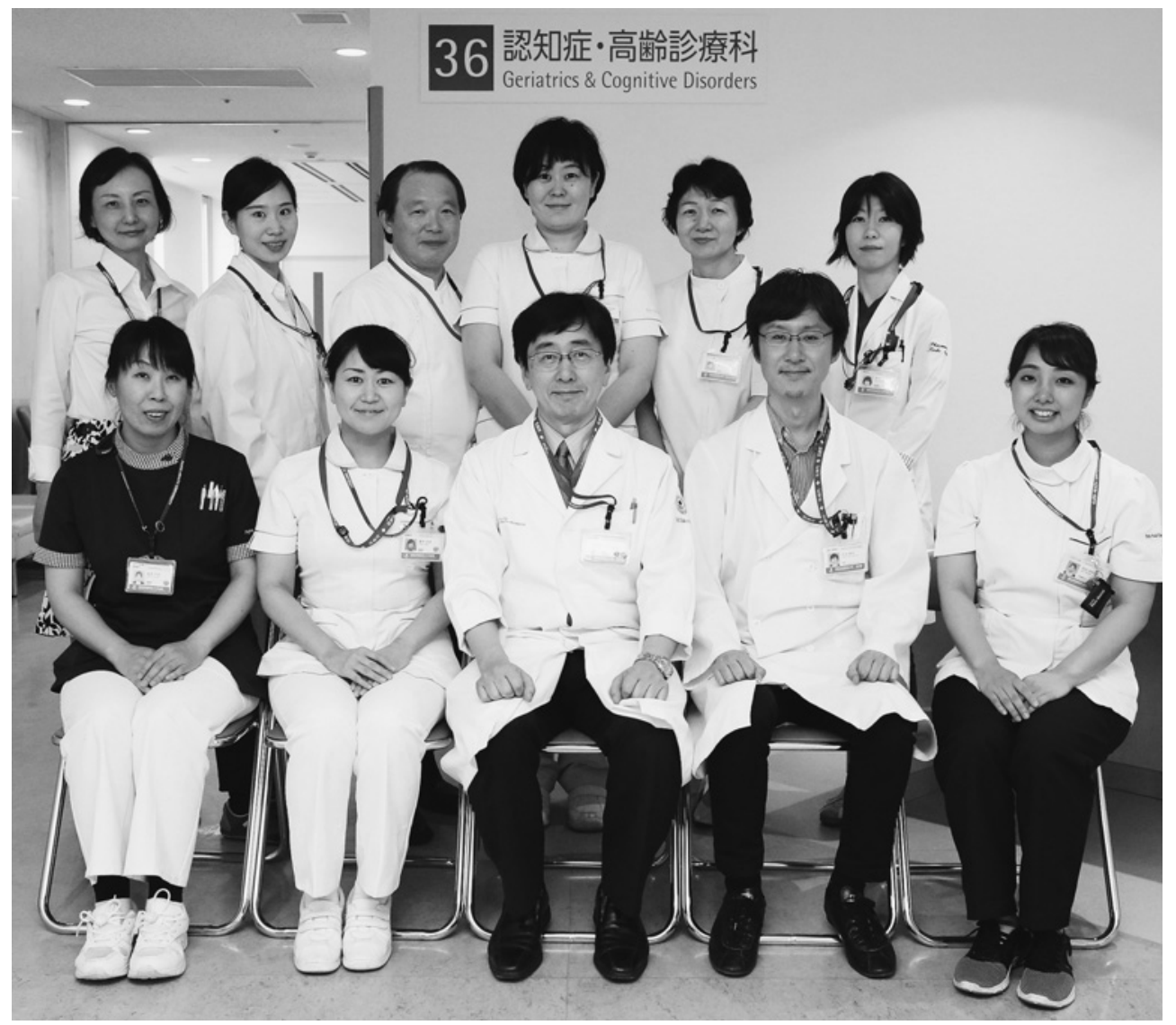

医局員集合写真 外来・認知症ケアチームスタッフとともに

授，講師の 2 名体制となりました。 外来には認知症疑い の患者さんが多数来られることから，リハビリテーショ ン部のスタッフの他, 放射線科の外山宏教授, 乾好貴講 師らとともに定例の症例検討会を行い，認知症診断のス キルアップに努めています。

\section{地域との連携}

本大学の特徵として, また, 高齢者医療の資源として, 医療科学部の金田嘉清教授, 都築晃講師らを中心に大学 としては珍しい地域包括ケア中核センターを持ち，まち かど保健室，訪問看護，居宅介護支援などの機能を有す るとともに，高度成長期の団地である UR 豊明団地の高 齢化の課題にも取り組みが行われており, 本学が立地す る豊明市や本医療圈にある東名古屋医師会も地域包括ケ アに向けての熱心な取り組みを行っていることから, 認 知症・高齢診療科ともタイアップして, 実践・研究を進
めていく基盤があります。そのような関係性もあり，豊 明市認知症初期集中支援チームの活動にもチーム員とし て加わり，愛知県内で普及している電子連絡帳を用いた バーチャルネットワークも生かしながら, チームの運営 にかかわっています。これらの活動を通じて, 地域の多 職種連携や地域住民を巻き込んだフィールド医学的アプ ローチも開始しています.

この他, 愛知県は, 認知症の人と家族の会が, 認知症 家族支援プログラムを標準的に動かしているなど，日本 でも最近本格的に注目されだした post-diagnostic supportを行っていく素地があります。また，名古屋市認 知症相談支援センター, 愛知県のオレンジタウン構想な どの活動もあり，認知症カフェや若年性認知症施策など においても, 連携をとりつつ活動と研究的取り組みを 行っています. 


\section{教育と今後に向けて}

教育面においても，当科ができたことで 2017 年度か ら加齢・高齢者系の講義が始まり, それまで関連の部署 でそれぞれに行われていた老年医学の教育を一元的に行 えるようになりました．2018年度には研修医向けのプ ログラムにも参加者が入り, 今後は専攻医向けのコース
も設置していく予定です。愛知県には国立長寿医療セン 夕ー, 名古屋大学老年科など全国的にも老年医学の中心 的役割を果たしている機関もあり，既に多くの協力も得 ていますが, 今後は本学からも発信を強め, 老年医学の 発展に寄与したいと考えています，私たちとともに超高 齢社会をリードしていける若手の参加も強く願っていま す，興味がある方は，遠虑なく連絡を下さい。 